\title{
Expression of two progesterone receptor isoforms in cumulus cells and their roles during meiotic resumption of porcine oocytes
}

\author{
Masayuki Shimada, Yasuhisa Yamashita, Junya Ito, Tetsuji Okazaki, \\ Kazumi Kawahata and Masahide Nishibori
}

Department of Applied Animal Science, Graduate School of Biosphere Science, Hiroshima University, Higashi-Hiroshima, Hiroshima 739-8528, Japan

(Requests for offprints should be addressed to Masayuki Shimada; Email: mashimad@ hiroshima-u.ac.jp)

\begin{abstract}
The present study aimed to investigate progesterone receptor (PR) gene expression in cumulus cells and their roles during meiotic resumption of porcine oocytes. The amount of PR-A or PR-B mRNA was analyzed by RT-PCR using primer sets for the PR-B region or the PR-A/B common region. The level of PR-B mRNA in cumulus cells was up-regulated by FSH and LH during the first $8 \mathrm{~h}$ of cultivation but the level significantly decreased at $12 \mathrm{~h}$. However, a high level of total PR mRNA was maintained up to a cultivation period of $20 \mathrm{~h}$. The level of PR-B protein in cumulus cells reached its maximum at 4 to $12 \mathrm{~h}$, whereas PR-A predominated in cumulus cells of cumulus-oocyte complexes (COCs) at $20 \mathrm{~h}$. Accompanying the shift in expression of $\mathrm{PR}$ isoforms, progesterone production in cumulus cells was significantly increased, and both the proliferative activity of cumulus cells during a 10- to 20-h cultivation period and the level of connexin-43, a major component of the gap junction, in cumulus cells significantly decreased. When COCs were cultured with FSH and $\mathrm{LH}$ for $10 \mathrm{~h}$ and then further cultured with additional RU486, there was a significant suppression in the shift in PR isoforms and in progesterone production, a loss of proliferative activity, and a decrease in connexin- 43 mRNA in cumulus cells. Moreover, treatment with RU486 after 10-h cultivation of COCs inhibited the meiotic resumption of oocytes and cumulus cell expansion. These results suggest that the induction of PR isoforms in cumulus cells and their binding to progesterone appear to impact on proliferation and differentiation in a time-dependent manner, and the shift from PR-B to PR-A may help mediate certain events.
\end{abstract}

Journal of Molecular Endocrinology (2004) 33, 209-225

\section{Introduction}

During in vitro meiotic maturation of cumulusoocyte complexes (COCs), it has been shown in human (Chian et al. 1999), rat (Zhang \& Armstrong 1989), cattle (Armstrong et al. 1996) and pig (Xia et al. 1994, Coskun et al. 1995, Shimada \& Terada $2002 a$ ) that progesterone is produced by cumulus cells, and that the level of progesterone is increased by stimulation with luteinizing hormone (LH), follicle-stimulating hormone (FSH) or forskolin. In our previous study (Yamashita et al. 2003), we showed that there was a significant positive correlation between the germinal vesicle breakdown (GVBD) rate of oocytes and the progesterone concentration in each well. When porcine COCs were cultured with a P450 scc inhibitor, progesterone production was almost completely suppressed in cumulus cells, and a reduction of the GVBD rate was also observed (Shimada \& Terada 2002a). Therefore, progesterone secreted by cumulus cells is clearly associated with meiotic maturation of porcine oocytes.

Many of the biological activities of progesterone are mediated by an intracellular receptor, a hormonally regulated DNA-binding protein that belongs to a superfamily of ligand-activated transcription factors (Beato et al. 1989). The progesterone receptors (PR) are expressed as two protein isoforms, $\mathrm{PR}-\mathrm{A}$ and $\mathrm{PR}-\mathrm{B}$, produced from a single gene by transcription at two distinct promoters and by translation initiation at two 
alternative AUG signals (Kraus et al. 1993, 1994). The distal and proximal promoters have putative binding sites for the estrogen receptor, called estrogen response element (ERE)-like regions (Kraus et al. 1993, 1994). In MCF-7 breast cancer cells, stimulation with estradiol-17 $\beta$ induced the expression of the PR gene (Fazzari et al. 2001). However, in granulosa cells, expression of the PR gene is not observed by stimulation with estrogen; the cAMP-protein kinase A (PKA) pathway has been documented to directly activate the distal promoter activity of the PR gene in the cells (Clemens et al. 1998). Park and Mayo (1991) reported that PR mRNA was highly expressed in the granulosa cells of large follicles in the ovaries of animals treated with pregnant mare's serum gonadotropin (PMSG) followed by human chorionic gonadotropin (hCG). In in vitro culture of rat granulosa cells, high concentrations of either FSH or LH stimulated PR gene expression (Natraj \& Richards 1993). In pigs, Slomczynska et al. (2000) showed that in granulosa cells of small antral follicles, PRs were not detected; however, the treatment of small follicles with LH or FSH in vitro induced the expression of the PR protein. Although it is known that the expression of the PR in granulosa cells is regulated by the gonadotropin surge, there has until now been no description of the ratios of PR-A to PR-B mRNA in cumulus cells surrounding oocytes during in vitro meiotic maturation of COCs.

It has been reported that PR-A is a truncated form of PR-B that lacks the first 164 N-terminal amino acids, and that PR-A and PR-B are functionally distinct mediators of progesterone action in the uterine epithelium (Conneely et al. 2001). Using a PR-A-deficient mouse model, Mulac-Jericevic et al. (2000) showed that the binding of progesterone to PR-B resulted in a gain of proliferative activity in the uterus; however, uterine expression of PR-A isoforms was required to oppose progesterone-induced proliferation through the PR-B function. Stimulation of PR-A by progesterone has also been reported to promote the differentiation of cells (Shiozawa et al. 2001, De-Vivo et al. 2002). Schuetz et al. (1996) showed that during in vivo ovulation, the loss of proliferative activity appeared to be closely associated with LH regulation of cumulus cell functions. The functions of differentiated cumulus cells, such as progesterone production, hyaluronan synthesis, or the close of gap junctional communication, were involved in the meiotic maturation of cumulus-enclosed oocytes (Tanghe et al. 2002). Judging from these reports, it is estimated that a high ratio of PR-A to PR-B expression plays an important role in cumulus cell differentiation; however, the functional differences between PR-A and PR-B in cumulus cells during meiotic resumption of porcine oocytes remain unclear.

In this study, we examined the time-dependent changes in PR gene expression in cumulus cells of COCs. The amount of PR-A or PR-B mRNA was analyzed by RT-PCR using primer sets for the $\mathrm{PR}-\mathrm{B}$ region or the $\mathrm{PR}-\mathrm{A} / \mathrm{B}$ common region. The protein levels of the two isoforms were detected by Western blotting analysis. To investigate the roles of PR in cumulus cells, COCs were cultured with RU486 or aminoglutethimide. The proliferative activity of cumulus cells, the amount of connexin-43 mRNA and progesterone production in cumulus cells, and the nuclear status of oocytes were analyzed.

\section{Materials and methods}

\section{In vitro maturation of porcine COCs}

Isolation of porcine COCs has been described previously (Shimada \& Terada 2001). The COCs were cultured in the maturation medium supplemented with or without both $20 \mathrm{ng} / \mathrm{ml}$ highly purified porcine FSH (NIDDK, Torrance, CA, USA) and $500 \mathrm{ng} / \mathrm{ml}$ porcine LH (NIDDK) $(\mathrm{FSH}+\mathrm{LH})$. Some COCs were cultured with 100 ng/ml estradiol-17 $\beta$ (Sigma Chemical Co., St Louis, MO, USA) or $5 \mu \mathrm{M}$ forskolin (Sigma). The maturation medium was modified NCSU37 (Petters \& Reed 1991) supplemented with essential amino acids (Gibco BRL, Grand Island, NY, USA), non-essential amino acids (Gibco BRL), $7 \mathrm{mM}$ taurine (Sigma) and $4 \mathrm{mM}$ hypoxanthine (Sigma). Estradiol-17 $\beta$ was dissolved in ethanol at $0.1 \mathrm{mg} /$ $\mathrm{ml}$, and was stored at $4{ }^{\circ} \mathrm{C}$. Forskolin was dissolved in DMSO (Sigma) at $50 \mathrm{mM}$ and stored at $-20^{\circ} \mathrm{C}$. The final concentration of estradiol-17 $\beta$ or forskolin was obtained by dilution with the basic medium. The oocytes were fixed with acetic acid/ethanol (1:3) for $48 \mathrm{~h}$, and stained with aceto-lacmoid before examination under a phasecontrast microscope $(400 \times)$ for evaluation of their 
Table 1 Primers used for the determination of porcine PR, connexin- 43 and beta-actin mRNA by RT-PCR

\section{Primer sequence}

mRNA

PR-A/B

PR-B

Connexin-43

Beta-actin
F: 5'-AGC CCA CAA TAC AGC TTC GAG-3'

R: 5'-TTT CGA CCT CCA AGG ACC AT-3'

F: 5'-ACT GAG CTG AAG GCA AAG GGT-3'

R: 5'-GTC CTG TCC CTG GCA GGG C-3'

F: 5'-TGTCTTCTTCAAGGGTGTTAAGG-3'

R: 5'-CACTCGCTTGTTTGTTGTAATTG-3'

F: 5'-CTA CAA TGA GCT GCG TGT GG-3'

R: 5'-TAG CTC TTC TCC AGG GAG GA-3'
Predicted product size (bp)

254

198

230

450
Amplification cycles

30

33

26

26

F, forward; R, reverse

chromatin configuration. Some COGs were cultured for $44 \mathrm{~h}$, and then the matured oocytes were used for in vitro fertilization and subsequent in vitro culture to the blastocyst stage, according to our previous study (Shimada et al. 2003).

\section{RNA isolation}

After cumulus cells were separated from 20 COCs, they were washed three times in PBS. Total RNA was extracted from cumulus cells using the SV Total RNA Isolation System (Promega, Madison, WI, USA), according to the instruction manual, and dissolved in nuclease-free water. The final RNA concentrations were determined by absorbance using a spectrophotometer.

\section{RT-PCR}

RT-PCR was performed according to a coupled one-step procedure using the Access RT-PGR System (Promega) with some modifications (Shimada et al. 2003). Briefly, $10 \mathrm{ng}$ total RNA were reverse transcribed at $48{ }^{\circ} \mathrm{C}$ for $45 \mathrm{~min}$, denatured at $94{ }^{\circ} \mathrm{C}$ for $2 \mathrm{~min}$, and amplified for 24 , 30 or 33 cycles of denaturation at $94^{\circ} \mathrm{C}$ for $30 \mathrm{~s}$, primer annealing at $58{ }^{\circ} \mathrm{C}(\mathrm{PR}-\mathrm{B}$, connexin-43) or $56{ }^{\circ} \mathrm{C}(\mathrm{PR}-\mathrm{A} / \mathrm{B}, \beta$-actin) for $1 \mathrm{~min}$, and extension at $68{ }^{\circ} \mathrm{C}$ for $1 \mathrm{~min}$, with a final extension step of $7 \mathrm{~min}$ at $68^{\circ} \mathrm{C}$. The amplified products were analyzed by electrophoresis on 2\% agarose gels. One primer set was directed at the sequence specific for the PR-B (i.e. within the 164 amino acids at the N-terminus) and therefore detected only mRNA transcripts encoding PR-B (Table 1, Fig. 1). The other primer set was directed to the section of the PR common to PR-A and PR-B
(PR-A/B) and therefore detected total PR mRNA (Table 1, Fig 1). The PR primers were based on the human sequence (GenBank accession no. NM00926). The primers used for amplification of connexin-43 were designed from the known cDNA sequence of porcine connexin-43 (GenBank accession no. X86026). $\beta$-Actin was used as a control for reaction efficiency and variations in concentrations of mRNA in the original RT reaction. The $\beta$-actin primers were based on the mouse sequence (GenBank accession no. NM009609).

\section{DNA sequence}

Direct sequence was carried out to identify RT-PGR products using a fluorescent dye terminator (DYEnamic ET Terminator Cycle Sequence Kit, Amersham Biosciences, Uppsala Sweden) and the ABI PRISM 377XL DNA Sequencer (Applied Biosystems, Foster City, CA, USA). According to the instructions supplied with the sequencing kit,

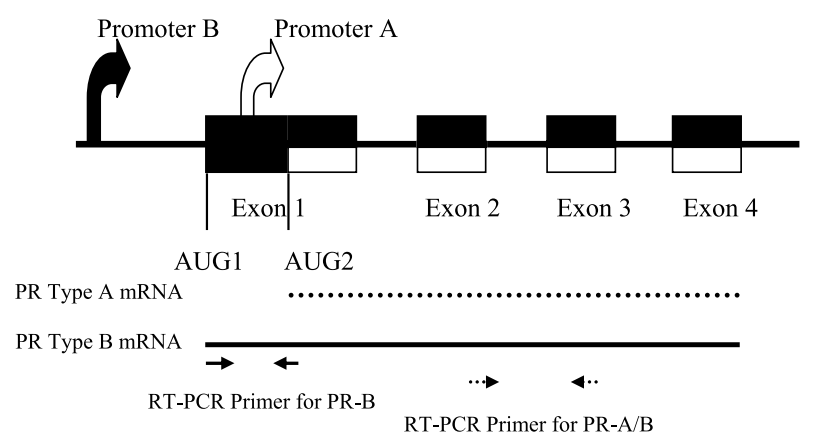

Figure 1 Schematic diagram indicating positions of the oligonucleotide primers on the putative porcine PR gene. Although unknown, the genomic structure of the porcine $P R$ is depicted in a similar fashion to the human PR gene (Gen Bank, accession number, NM 000926). 
the cDNA fragments were mixed with four dye-labeled dideoxynucleotides as terminators, a thermally stable AmpliTaq DNA polymerase, and upstream or downstream primer, then set on the thermal cycler for the sequencing reaction. Extended products were analyzed on the DNA sequencer.

\section{Western blotting}

Western blotting analysis was based on the procedures reported in our previous study (Shimada et al. 2001). After cultivation of COCs, cumulus cells were separated from the COCs. The cumulus cells were lysed in Laemmli sample buffer. After denaturing by boiling for $5 \mathrm{~min}$, each protein sample $(4 \mu \mathrm{l})$ was separated by SDS-PAGE on a $7 \cdot 5 \%$ polyacrylamide gel (Amersham Biosciences), then transferred onto a PVDF membrane (Amersham Biosciences). The membrane was blocked by $5 \%$ (w/v) nonfat dry milk (Amersham Biosciences), then incubated with anti-PR rabbit polyclonal antibody (Santa Cruz Biotechnology, Inc., Santa Cruz, CA, USA) which allowed recognition of both PR-A and PR-B at 1:200 dilution overnight at $4{ }^{\circ} \mathrm{C}$. After four washes in $0 \cdot 1 \%$ (v/v) Tween 20 (Sigma)/PBS (T-PBS), the membranes were treated with horseradish-peroxidase-labeled anti-rabbit IgG (1:5000, Amersham Biosciences) for $1 \mathrm{~h}$ at room temperature. After four washes of $10 \mathrm{~min}$ each with T-PBS, peroxidase activity was visualized using the ECL Plus Western blotting detection system (Amersham Biosciences), according to the manufacturer's instructions.

\section{5-Bromo-2-deoxyuridine (BrdU) labeling for cell proliferation}

The proliferative response of cumulus cells was measured with a BrdU proliferation kit (Roche Molecular Biochemicals, Basel, Switzerland). In short, the 10 COCs in each well were cultured with a $100 \mu \mathrm{M}$ BrdU for a 10-h period. At the end of cultivation, cumulus cells were separated from COGs, then washed 3 times with PBS. They were suspended at $5 \times 10^{3}$ cells/well in the 96-well culture plates, and then the plates were dried for $1 \mathrm{~h}$ at $60^{\circ} \mathrm{C}$. FixDenat solution $(200 \mu \mathrm{l})$ was added to each well, and the plates were incubated for $30 \mathrm{~min}$ at $25^{\circ} \mathrm{C}$. The FixDenat solution was removed and peroxidase-labeled anti-BrdU mono- clonal antibody $(100 \mu \mathrm{l} /$ well $)$ that had been diluted 100 -fold with the antibody dilution solution was added, before the plates were incubated for $1 \mathrm{~h}$ at $25^{\circ} \mathrm{C}$. The peroxidase-labeled anti-BrdU monoclonal antibody solution was removed, and each well was washed three times with PBS $(200 \mu \mathrm{l}$ each). A tetramethylbenzidine solution $(100 \mu \mathrm{l} /$ well) was added, and the plates were incubated for $15 \mathrm{~min}$. After adding $1 \mathrm{M} \mathrm{H}_{2} \mathrm{SO}_{4}(25 \mu \mathrm{l} /$ well $)$ to stop the enzymatic reaction, the absorbance at $450 \mathrm{~nm}$ was measured with a microplate reader.

\section{Treatment of COCs with RU486}

Some COCs were cultured with FSH, LH and $20 \mathrm{ng} / \mathrm{ml}$ progesterone, and/or $0 \cdot 25,2 \cdot 5$ or $25 \mu \mathrm{M}$ RU486 (Sigma) for $10 \mathrm{~h}$. Other COCs were pre-cultured with FSH and $\mathrm{LH}$ for $10 \mathrm{~h}$ and then further cultured with $0 \cdot 25,2 \cdot 5$ or $25 \mu \mathrm{M}$ RU486 for an additional $10 \mathrm{~h}$. The range of RU486 concentrations has been used to test progesterone receptor function in granulosa cells (Natraj \& Richards 1993, Park et al. 2000, VandeVoort et al. 2000, Mussche \& D'Herde 2001, Shao et al. 2003). RU486 was dissolved in ethanol at $25 \mathrm{mM}$, and was stored at $4{ }^{\circ} \mathrm{C}$. Each final concentration was obtained by dilution in the maturation medium.

\section{Treatment of COCs with aminoglutethimide}

COCs were cultured for $20 \mathrm{~h}$ in maturation medium supplemented with $0.5 \mathrm{mM}$ aminoglutethimide (AGT, Sigma). In our previous study (Shimada \& Terada 2002a), progesterone production in cumulus cells of COCs during in vitro maturation was decreased by AGT in a dosedependent fashion, and the maximum inhibitory effect was observed at $0.5 \mathrm{mM}$. AGT was dissolved in DMSO at $0.5 \mathrm{M}$, and was stored at $-20^{\circ} \mathrm{C}$. Each final concentration was obtained by dilution in the maturation medium.

\section{Statistical analysis}

Statistical analyses of all data from three or four replicates for comparison were carried out by one-way ANOVA followed by Duncan's multiple-range test (Statview; Abacus Concepts, Inc., Berkeley, CA, USA). All percentage data were subjected to arcsine transformation before analysis. 


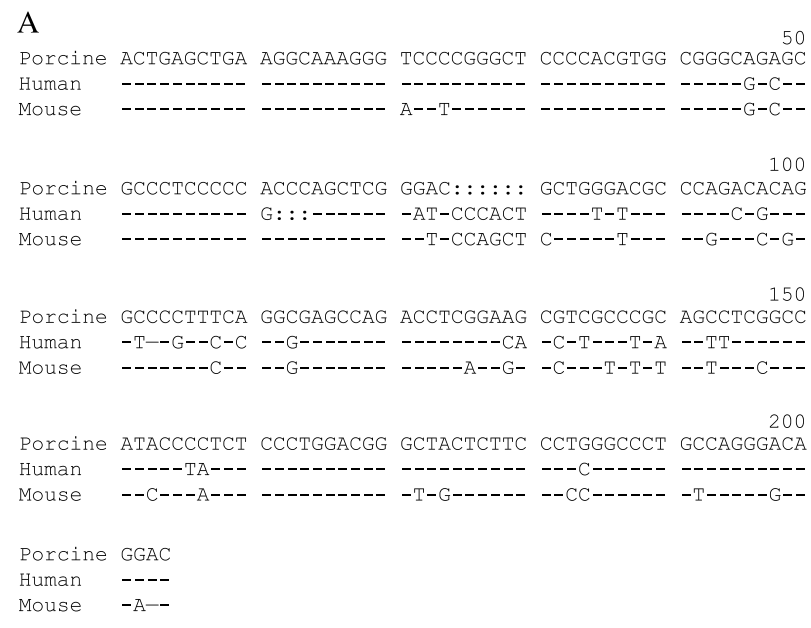

B

Porcine AGCCCACAAT ACAGCTTCGA GTCATTACCT CAGAAGATTT GTTTAATCTG Mouse - -

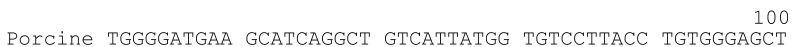

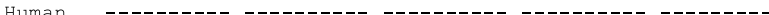
Mouse C------- - - -

150 Porcine GTAAGGTCTT CTTTAAAAGg GCAATGGAAG GGCAGCACAA CTACTTATGT Human - - - - - - - - - -

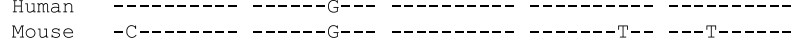
200 Porcine GCTGGAAGAA ACGACTGCAT TGTTGATAAA ATCCGCAGAA AAAACTGCCC Human - - - - - - - - T- - - -

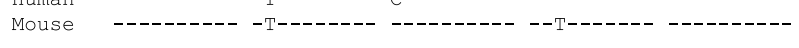

250 Porcine AGCTTGTCGC CtTAgAAAgt GCTGtCAGGC TGGCATGGTC CtTGGAGGCC Human - - A-- - - - Mouse ---A-----T $-\mathrm{G}--------\mathrm{T}----------------------\mathrm{T}-$

Porcine GAAA

Human ----

Figure 2 Comparison of partial cDNA sequences of porcine PR-B (A) and PR-A/B common region (B) with human PR (accession number, NM 000926) and mouse PR (accession number, NM 008829). Conserved nucleotides are indicated by a dash (-) and deletions by a colon (:).

\section{Results}

\section{Regulation of PR gene expression in cumulus cells of COCs}

Partial cDNAs were amplified by RT-PCR from porcine cumulus cells using primers that are sequence-specific for human PR-B (i.e. within the 164 amino acids at the N-terminus) and common to human PR-A and PR-B (PR-A/B). Each sequence was compared for homology with the human and mouse cDNA sequences. The similarity of the partial porcine PR-B region sequence was 83.3\% to human PR-B and $82 \cdot 8 \%$ to mouse PR-B (Fig. 2A). The porcine PR common region sequence showed a high degree of similarity to human PR (98.1\%) and mouse PR (90.5\%) (Fig. 2B). Sequence comparisons indicate that the partial porcine cDNAs amplified with human PR primers conformed to the porcine $\mathrm{PR}-\mathrm{B}$ region and $\mathrm{PR}$ common region (PR-A/B) respectively.

After 4-h cultivation of COCs without stimulation, the total PR mRNA (PR-A/B) level in cumulus cells was very low (Fig. 3). This level was not significantly increased by stimulation with estradiol-17 $\beta$ (Fig. 3). Cultivation with FSH for $4 \mathrm{~h}$ significantly increased the level of total PR-A/B mRNA and PR-B mRNA in cumulus cells of COCs (Fig. 3). Moreover, the higher levels of PR gene expression in cumulus cells that were induced by FSH were comparable with those in cumulus cells stimulated by $5 \mu \mathrm{M}$ forskolin (Fig. 3) which elevated cAMP level in cumulus cells to the same

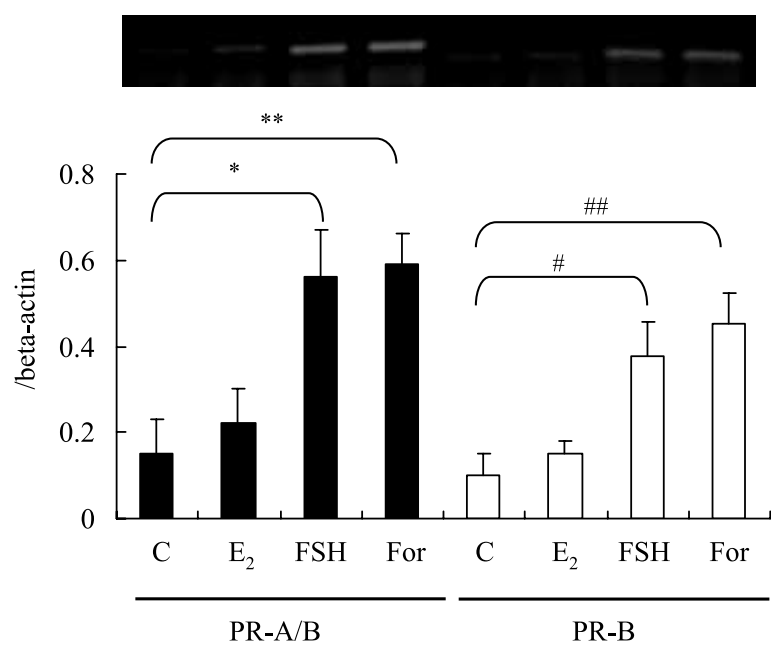

Figure 3 The expression of the PR gene in cumulus cells which were cultured for $4 \mathrm{~h}$ with estradiol-17 $\beta$, FSH or forskolin. COCs were cultured for $4 \mathrm{~h}$ without any hormones (control, C), with $100 \mathrm{ng} / \mathrm{ml}$ estradiol-17 $\beta$ $\left(E_{2}\right)$, with $20 \mathrm{ng} / \mathrm{ml} \mathrm{FSH}(\mathrm{FSH})$ or with $5 \mu \mathrm{M}$ forskolin (For). ${ }^{*} P<0.01$, significant effect of $\mathrm{FSH}$ on the level of PR-A / $B ;{ }^{* \star} P<0.01$, significant effect of forskolin on the level of $P R-A / B ; \# P<0.01$, significant effect of $F S H$ on

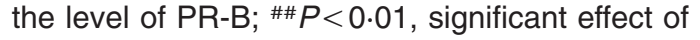
forskolin on the level of PR-B. Values are means \pm S.E.M. of 3 replicates. 
A
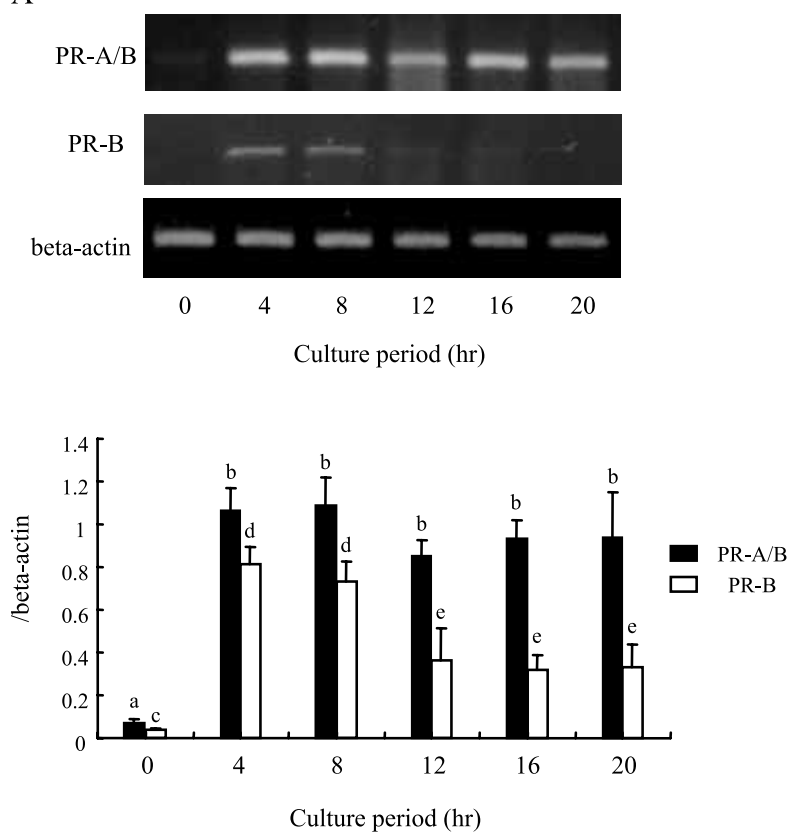

B
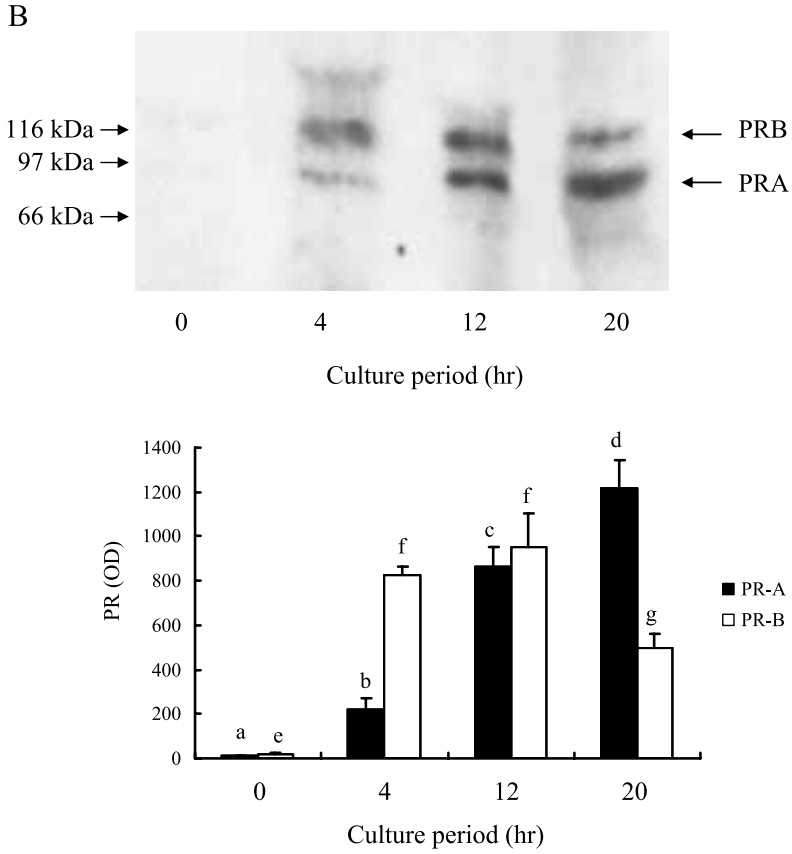

Figure 4 Time-dependent changes of PR expression in cumulus cells of COCs which were cultured with FSH and LH. (A) RT-PCR analysis of PR-A/B or PR-B mRNA in cumulus cells. The intensity of the objective bands was quantified by densitometric scanning using a Gel-Pro Analyzer (Media Cybernetics, Silver Spring, MD, USA). The respective values of PR-A/B and PR-B were normalized according to those of beta-actin to evaluate arbitrary units of the relative abundance of the targets. ${ }^{a-b}, c-e$ Values with different letters are significantly different $(P<0.05)$. Values are means \pm S.E.M. of 3 replicates. (B) Western blotting analysis of PR in cumulus cells. The intensity of the bands was analyzed using a Gel-Pro Analyzer. a-d, e-g Values with different letters are significantly different $(P<0 \cdot 05)$. Values are means \pm S.E.M. of 3 replicates.

extent as FSH (Racowsky 1985, Shimada \& Terada 2002b).

\section{Time-dependent changes of PR-A and PR-B expression in cumulus cells of COCs}

To investigate the time-dependent changes in PR gene expression in cumulus cells, COCs were cultured with FSH and LH. Our data showed that the level of total PR mRNA (PR-A/B) was very low in cumulus cells just after collection from their follicles (Fig. 4A). The expression of PR-B in cumulus cells was up-regulated by FSH and $\mathrm{LH}$ during the first $8 \mathrm{~h}$ of cultivation, but the level had significantly decreased by $12 \mathrm{~h}$ of cultivation (Fig. 4A). Still, a high level of total PR mRNA was maintained up to the 20-h cultivation period (Fig. 4A). The result of Western blotting analysis of PR is shown in Fig. 4B. The level of PR-B protein in cumulus cells reached its maximum at 4-12 h. However, further cultivation for $8 \mathrm{~h}$ (a total 20-h cultivation period) significantly decreased the level of PR-B protein in cumulus cells. The level of PR-A protein significantly increased in a timedependent fashion when COGs were cultured with FSH and LH. The maximum level was reached at $20 \mathrm{~h}$ of cultivation. These results for mRNA and protein levels indicated that PR-B was initially expressed in cumulus cells, whereas the level of PR-B decreased and PR-A predominated in cumulus cells of COCs after $12 \mathrm{~h}$ of cultivation.

\section{The roles of PR-A and PR-B in proliferation of cumulus cells}

During the first 10-h cultivation period, the incorporation of BrdU in cumulus cells cultured with both FSH and LH was significantly lower than that in cumulus cells of COCs which were cultured without any hormones (Fig. 5A). A further decrease of proliferative activity was induced by the addition of $2 \cdot 5 \mu \mathrm{M}$ RU486 to FSH+LH-containing 
medium, but the difference was not significant. In the next experiment, we investigated the additional effects of $20 \mathrm{ng} / \mathrm{ml}$ progesterone in the FSH+LHcontaining medium on the inhibitory function of the gonadotropins. When COGs were cultured with FSH, LH and $20 \mathrm{ng} / \mathrm{ml}$ progesterone for $10 \mathrm{~h}$, the incorporation of BrdU in cumulus cells increased significantly compared with that of COGs without the additional progesterone (Fig. 5A). The positive effect of progesterone on cell proliferation was significantly suppressed by RU486 in a dose-dependent fashion (Fig. 5A). The effect was reached at $2 \cdot 5 \mu \mathrm{M}$. In cumulus cells of COCs which were cultured with progesterone and/or RU486, the level of PR-B mRNA was comparable to that of COCs cultured with only gonadotropin (Fig. 5B). The progesterone production by COCs could not be affected by treatment with RU486 (Fig. 5G). Thus, during the first 10-h cultivation period, the high level of PR-B in cumulus cells may have the potential to promote the proliferation of the cells.

We have already shown that progesterone production in cumulus cells is significantly increased after $10 \mathrm{~h}$ of cultivation (Shimada et al. 2002). In Fig. 6D, 29.8 $\pm 4 \cdot 1 \mathrm{ng} / \mathrm{ml}$ progesterone were secreted by FSH- and LH-stimulated COCs. Progesterone has been shown to be a potent antagonist of proliferation of uterine epithelium when PR-A is expressed in the cells (MulacJericevic et al. 2000). Since the relatively high ratios of PR-A to PR-B were observed in cumulus cells after 10-h cultivation of COCs, it was estimated that the proliferative activity of cumulus cells during the 10 - to 20 -h cultivation period would decrease due to the binding of progesterone to PR-A. In order to test this hypothesis, COCs were pre-cultured with FSH+LH for $10 \mathrm{~h}$ and then further cultured with FSH, LH and/or RU486 for $10 \mathrm{~h}$. The proliferative activity in cumulus cells during the latter 10 -h cultivation period was increased by RU486 in a dose-dependent fashion (Fig. 6A). The rate of proliferative activity in cumulus cells cultured with FSH+LH and either 2.5 or $25 \mu \mathrm{M}$ RU486 after $10 \mathrm{~h}$ of cultivation with $\mathrm{FSH}+\mathrm{LH}$ was significantly higher than that in cumulus cells cultured with FSH+LH for $20 \mathrm{~h}$ (Fig. $6 \mathrm{~A})$. The addition of $25 \mu \mathrm{M}$ RU486 suppressed the decrease of PR-B mRNA and protein level in cumulus cells of COCs which were cultured with FSH and LH for $20 \mathrm{~h}$ (Fig. 6B and C). The level of
PR-B mRNA in cumulus cells treated with RU486 was significantly higher than that in cumulus cells of COCs which were cultured with FSH and LH for $20 \mathrm{~h}$, whereas the level of total PR mRNA (PR-A/B) was not affected by the addition of RU486 (Fig. 6B). Moreover, the addition of RU486 to FSH+LH-containing medium after $10 \mathrm{~h}$ of cultivation significantly suppressed progesterone production by COCs (Fig. 6D). Thus, the further 10-h cultivation of COCs with RU486 after the 10-h cultivation with FSH and LH induced both a decrease in progesterone production and a suppression of the decrease in PR-B levels, which resulted in the failure of $\mathrm{FSH}_{-}$and LH-induced loss of proliferative activity in cumulus cells.

\section{Time-dependent changes of connexin-43 gene expression in cumulus cells and the regulation by progesterone}

Differentiated cumulus cells have been shown to be involved in meiotic resumption of cumulusenclosed oocytes (Tanghe et al. 2002). One of the functions they perform is the closing of gap junctional communication between outer layers of cumulus cells (Larsen et al. 1986, 1987, Isobe et al. 1998). We have already reported that the connexin-43 protein, a major component of the gap junction, was up-regulated by cultivation with FSH and LH for $8 \mathrm{~h}$, whereas the level significantly decreased after $12 \mathrm{~h}$ of cultivation and remained so for up to $28 \mathrm{~h}$ (Shimada et al. 2001). The present results showed that the level of connexin-43 gene expression was significantly increased and reached a maximum at $8 \mathrm{~h}$ (Fig. 7A). The sequence of the RT-PGR product was identified as part of the porcine connexin-43 cDNA (GenBank accession no. X86026), by using the Basic Local Alignment Search Tool (BLAST) (Altschul et al. 1990). However, further cultivation suppressed the expression of the connexin-43 gene, and this lower level was maintained for up to $20 \mathrm{~h}$ (Fig. 7A). The levels of connexin-43 mRNA at 16 and $20 \mathrm{~h}$ were significantly lower than those in cumulus cells of COGs that were cultured for $8 \mathrm{~h}$ (Fig. 7A). Thus, the disappearance of connexin-43 protein in cumulus cells of COCs could result from the suppression of connexin-43 gene expression, concomitantly with the shift in expression of PR isoforms. 
A
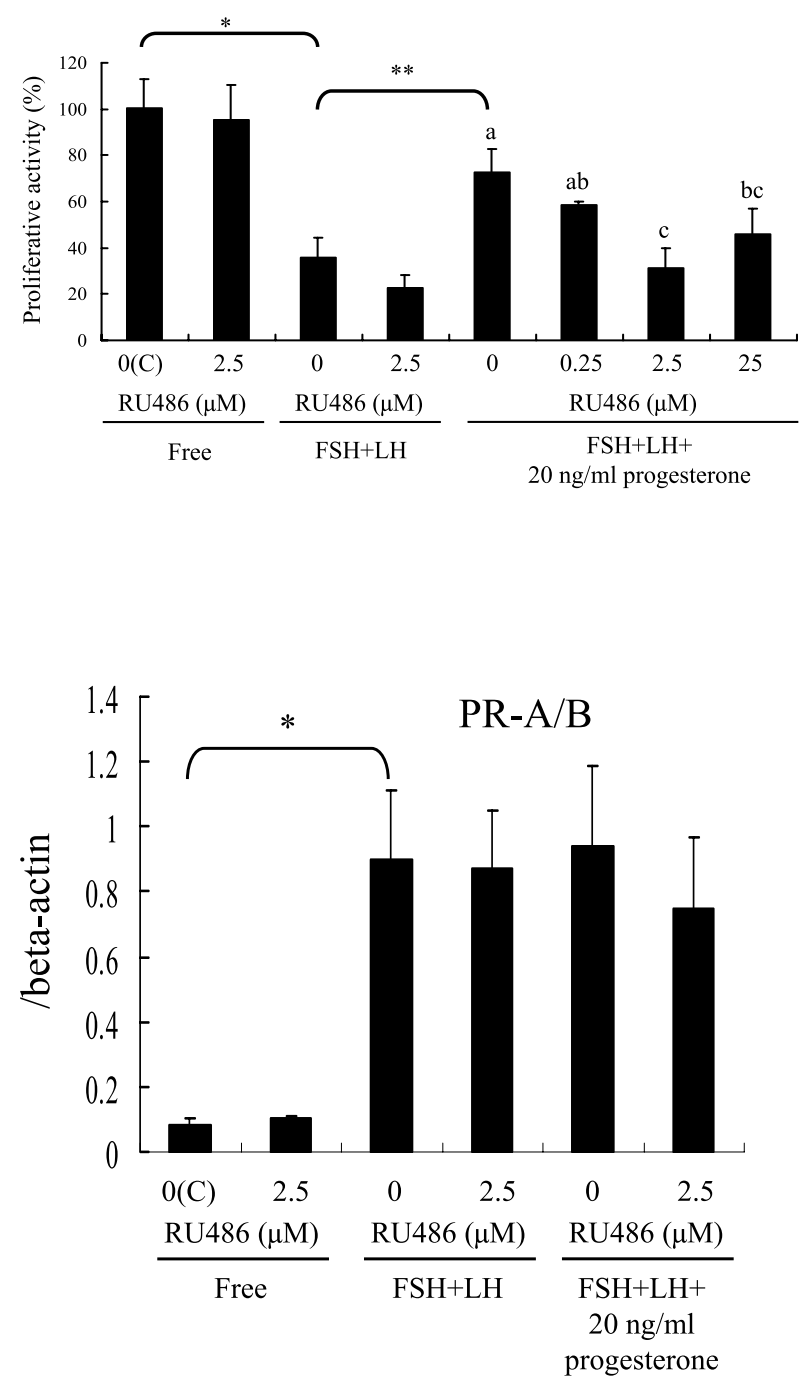

C

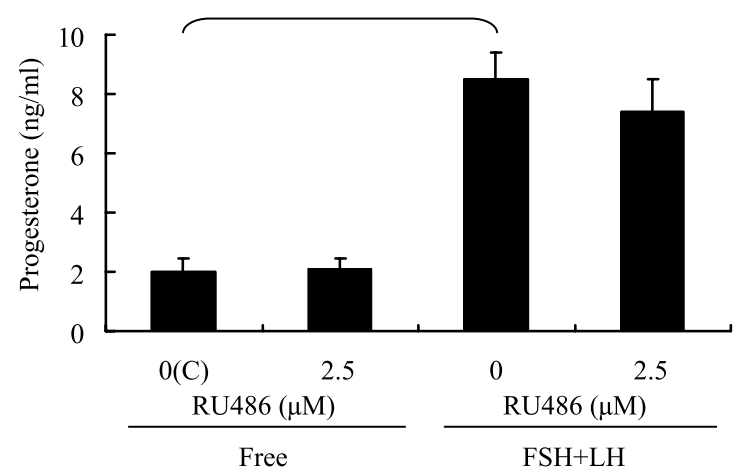

B

PR-A/B

PR-B

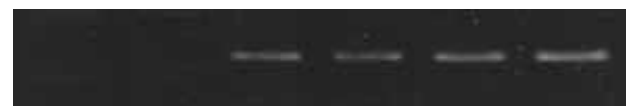

beta-actin

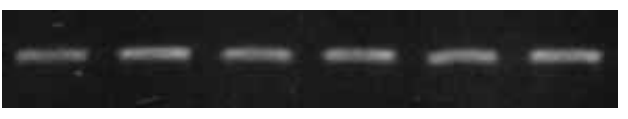

$\begin{array}{llllll}0(\mathrm{C}) & 2.5 & 0 & 2.5 & 0 & 2.5\end{array}$

$\frac{\mathrm{RU} 486(\mu \mathrm{M})}{\text { Free }} \quad \frac{\mathrm{RU} 486(\mu \mathrm{M})}{\mathrm{FSH}+\mathrm{LH}} \quad \frac{\mathrm{RU} 486(\mu \mathrm{M})}{\mathrm{FSH}+\mathrm{LH}+}$

$20 \mathrm{ng} / \mathrm{ml}$

progesterone

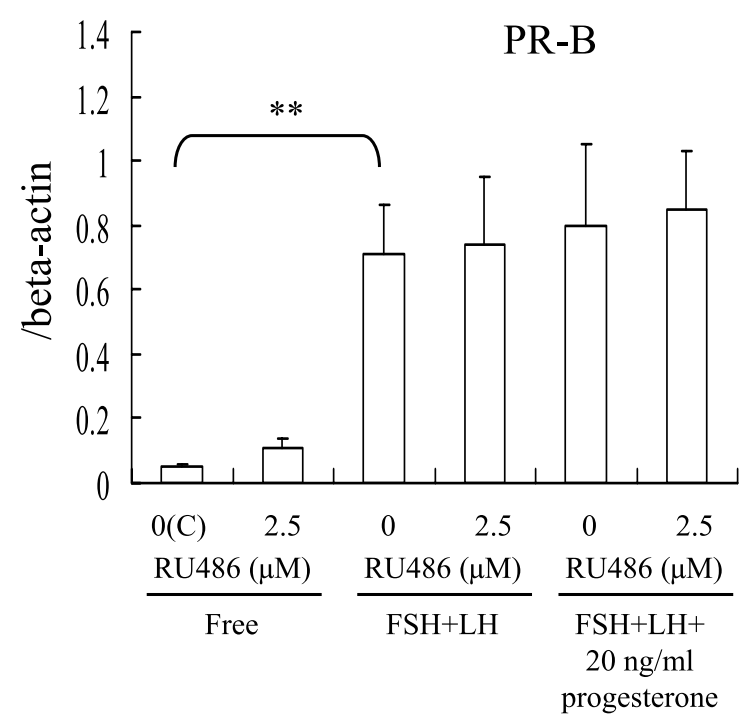


Zhao et al. (1996) revealed that progesterone down-regulated the expression of the connexin- 43 gene in human myometrial cells. In the next experiment, we investigated the effects of RU486 or aminoglutethimide (AGT) on connexin-43 gene expression in cumulus cells. When GOGs were cultured for $8 \mathrm{~h}$, there was no significant difference in the level of connexin- $43 \mathrm{mRNA}$ in cumulus cells among the treatment groups (Fig. 7B). The level of connexin-43 mRNA was decreased by 20-h cultivation with FSH+LH (Fig. 7A and C). However, 20-h cultivation of COCs with FSH+LH and $0.5 \mathrm{mM}$ AGT significantly suppressed the decrease in connexin-43 levels in cumulus cells as compared with those in cumulus cells cultured without AGT (Fig. 7C). Moreover, the addition of RU486 to FSH+LH-containing medium after 10 h-cultivation with $\mathrm{FSH}+\mathrm{LH}$ also induced the failure of disappearance of connexin-43 mRNA in cumulus cells (Fig. 7C).

\section{Effects of RU486 or AGT on meiotic resumption of cumulus-enclosed oocytes}

To investigate whether the binding of progesterone to PR in cumulus cells during a 10- to 20-h cultivation period induced the meiotic resumption of oocytes, COCs were cultured with RU486 after a 10-h cultivation with FSH and LH. As shown in Fig. 8A, the proportion of oocytes undergoing GVBD significantly decreased as the concentration of RU486 was increased in the medium with $\mathrm{FSH}+\mathrm{LH}$. When FSH+LH-stimulated progesterone production was suppressed by $0.5 \mathrm{mM}$ AGT, a significantly lower GVBD rate than that in oocytes cultured without the drug was also observed (Fig. 8A).
It has been reported that the addition of RU486 to the in vitro culture medium from 0 to $24 \mathrm{~h}$ cannot suppress meiotic resumption of mouse oocytes (Batten et al. 1989). When COCs were cultured with FSH, LH and $25 \mu \mathrm{M}$ RU486 for $20 \mathrm{~h}$, the proportion of oocytes exhibiting GVBD was comparable to that in oocytes cultured without the drug (Fig. 8B). However, a further 24-h cultivation with RU486 significantly reduced the proportion of oocytes that reached the metaphase of meiosis II (MII) stage (Fig. 8B). The matured oocytes which were cultured in the presence of FSH and LH supplemented with or without RU486 were used for in vitro fertilization. After 5 days cultivation of oocytes, $20 \pm 3 \cdot 4 \%$ of the matured oocytes without RU486 treatment developed to the blastocyst stage, whereas the rate was significantly decreased $(3 \cdot 3 \pm 1 \cdot 1 \%)$ by treatment with RU486. Additionally, the proliferative activity of cumulus cells which were cultured for $44 \mathrm{~h}$ with $\mathrm{FSH}, \mathrm{LH}$ and 0.25 or $2 \cdot 5 \mu \mathrm{M}$ RU486 was significantly lower than that in cumulus cells of COCs cultured without RU486 for 20 h (Fig. 8G). Thus, the oocytes matured without the stimulation of PR in cumulus cells have little developmental potential.

Expanded COGs were observed after 44-h cultivation with FSH and LH (Fig. 8 Da). However, when COCs were cultured for $34 \mathrm{~h}$ with the addition of RU486 following 10-h cultivation in FSH+LH-containing medium, cumulus cells remained packed around the oocytes with little visible expansion (Fig. 8Db). On the other hand, $44 \mathrm{~h}$ of cultivation with FSH+LH and RU486 resulted in dispersion of cumulus cells from oocytes, but the majority of the cells became flattened on the culture dish with few remaining suspended in the expanded complex (Fig. 8Dc).

\footnotetext{
Figure 5 Proliferative activity of cumulus cells of COCs during the first $10 \mathrm{~h}$ of cultivation. (A) COCs were cultured for $10 \mathrm{~h}$ in $\mathrm{FSH}+\mathrm{LH}$-containing medium with or without $20 \mathrm{ng} / \mathrm{ml}$ progesterone. Some COCs were cultured in $20 \mathrm{ng} / \mathrm{ml}$ progesterone-containing $\mathrm{FSH}+\mathrm{LH}$ medium with RU486 (0 to $25 \mu \mathrm{M})$. Data are expressed as percentage of the absorbance value at $450 \mathrm{~nm}$ in cumulus cells of COCs which were cultured for $10 \mathrm{~h}$ in the Free medium with $100 \mu \mathrm{M}$ BrdU. C (control), COCs were cultured for $10 \mathrm{~h}$ without any hormones. Free, COCs were cultured for $10 \mathrm{~h}$ with or without $2.5 \mu \mathrm{M}$ RU486. ${ }^{*} P<0.01$, significant effect of $\mathrm{FSH}+\mathrm{LH}$ on proliferative activity of cumulus cells; ${ }^{* \star} P<0.01$, significant effect of the addition of $20 \mathrm{ng} / \mathrm{ml}$ progesterone to $\mathrm{FSH}+\mathrm{LH}$-containing medium. ${ }^{a-c}$ Different superscripts are significantly different at the $P<0.05$ level. Values are means \pm S.E.M. of 4 replicates. (B) RT-PCR analysis of PR-A/B or PR-B mRNA in cumulus cells when COCs were cultured for $10 \mathrm{~h}$. The respective values of $\mathrm{PR}-\mathrm{A} / \mathrm{B}$ and PR-B were normalized according to those of beta-actin to evaluate arbitrary units of the relative abundance of the targets. ${ }^{*} P<0.01$, significant effect of $\mathrm{FSH}+\mathrm{LH}$ on the level of PR-A/B; ${ }^{* *} P<0.01$, significant effect of $\mathrm{FSH}+\mathrm{LH}$ on the level of PR-B. Values are means \pm S.E.M. of 3 replicates. (C) The level of progesterone in the medium where COCs had been cultured for $10 \mathrm{~h}$. ${ }^{*} P<0.01$, significant effect of $\mathrm{FSH}+\mathrm{LH}$ on the level of progesterone in the cultured medium. Values are means \pm S.E.M. of 3 replicates.
} 


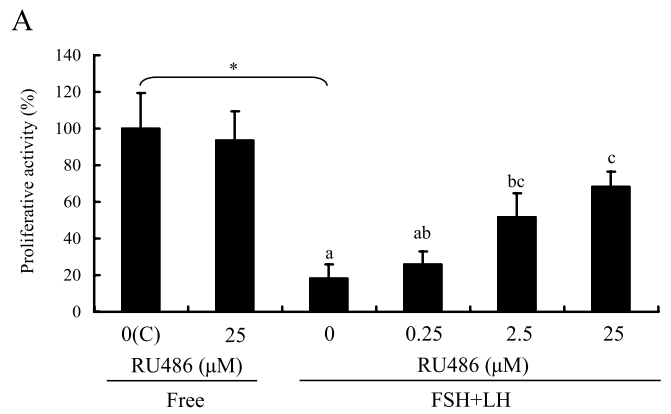

B
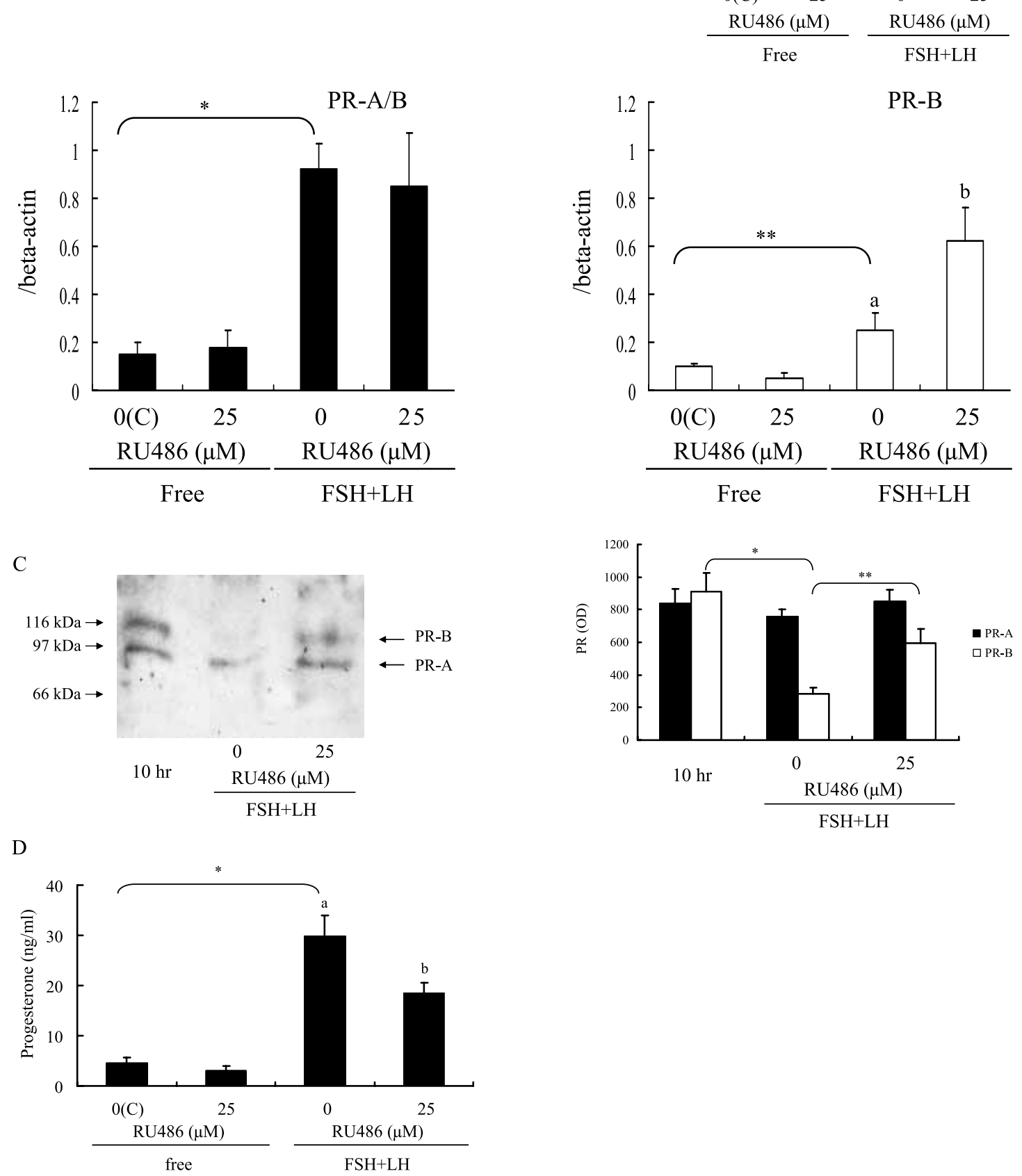


\section{Discussion}

Promoters within the PR gene have putative binding sites for the estrogen receptor, known as estrogen response element (ERE)-like regions (Kraus et al. 1993, 1994). However, in granulosa cells, the expression of the PR gene was not apparently stimulated by estrogen; rather, the cAMP-PKA pathway has been documented to directly activate the distal promoter activity of the PR gene in these cells (Clemens et al. 1998). The present study showed that the expression of both PR-A and PR-B in cumulus cells was up-regulated by either FSH or forskolin in cumulus cells. It is well known that the level of cAMP in cumulus cells of COCs is elevated by the presence of FSH or forskolin (Racowsky 1985, Shimada \& Terada 2002b). These results suggested that the expression of the PR gene was stimulated by the cAMP-PKA pathway in cumulus cells as well as in granulosa cells.

In rat gonadotropes or uterus where the expression of PR is up-regulated by estrogen, it has been reported that progesterone leads to a down-regulation of PR (Turgeon \& Waring 2000, Fang et al. 2002). However, the inhibitory effect of progesterone on PR expression was not observed in granulosa cells (Iwai et al. 1991, Natraj \& Richards 1993, Jo et al. 2002). In the present study, total PR mRNA level in cumulus cells of COCs which were cultured with $\mathrm{FSH}$ and $\mathrm{LH}$ was maintained at a high level for up to $20 \mathrm{~h}$ of cultivation. Interestingly, we found that the level of PR-B decreased in cumulus cells from 12 to $20 \mathrm{~h}$ of cultivation, concomitantly with an increasing level of progesterone secreted by COCis. Natraj and Richards (1993) have also reported that PR-A mRNA appears to persist longer than PR-B mRNA in LH-stimulated rat granulosa cells. We examined the relationship between the decrease in PR-B levels and the high levels of secreted progesterone. The results showed that the reduction of PR-B was suppressed by the addition of RU486 following a 10-h cultivation with FSH and LH, but there was no effect on the total level of PR. Judging from these results, it is estimated that the pattern of PR expression, but not the amount of PR expression, is regulated by both the gonadotropin-induced cAMP-PKA pathway and the progesterone-PR pathway in cumulus cells during meiotic resumption of porcine oocytes.

When PR-B predominated in cumulus cells of GOCs, stimulation with progesterone increased the proliferative activity of cumulus cells. The proliferative activity was decreased by FSH and LH from 10 to $20 \mathrm{~h}$ of cultivation. The decreases of both the proliferative activity and the level of PR-B in cumulus cells were restrained when COCs were cultured with the addition of RU486 following 10-h cultivation with FSH and LH. Since PR-A null mice have decreased ovulation rates (MulacJericevic et al. 2000), and those that lack only the B form are not affected (Mulac-Jericevic et al. 2003), it

\footnotetext{
Figure 6 The effects of the addition of RU486 following 10-h cultivation with FSH+LH on the proliferative activity of cumulus cells. (A) COCs were cultured for $10 \mathrm{~h}$ with $\mathrm{FSH}+\mathrm{LH}$, and then cultured for a further 10-h with $0,2.5$ or $25 \mu \mathrm{M}$ RU486. Data are expressed as percentage of the absorbance value at $450 \mathrm{~nm}$ in cumulus cells of COCs which were cultured for $10 \mathrm{~h}$ with the addition of $100 \mu \mathrm{M}$ BrdU following 10-h cultivation without any hormones. C (control), COCs were cultured for $10 \mathrm{~h}$ with the addition of $100 \mu \mathrm{M}$ BrdU following 10-h cultivation without any hormones. Free, COCs were cultured for $10 \mathrm{~h}$ with the addition of $100 \mu \mathrm{M}$ BrdU and/or $25 \mu \mathrm{M}$ RU486 following 10-h cultivation without any hormones. $\mathrm{FSH}+\mathrm{LH}$, COCs were cultured for $10 \mathrm{~h}$ with the addition of $100 \mu \mathrm{M}$ BrdU and RU486 (0 to $25 \mu \mathrm{M})$ following 10-h cultivation with $\mathrm{FSH}+\mathrm{LH} .{ }^{*} P<0.01$, significant effects of $\mathrm{FSH}+\mathrm{LH}$ on proliferative activity of cumulus cells. ${ }^{a-c}$ Different superscripts are significantly different at the $P<0.05$ level. Values are means \pm S.E.M. of 4 replicates. (B) RT-PCR analysis of PR-A/B or PR-B mRNA in cumulus cells when COCs were cultured for $20 \mathrm{~h}$. The respective values of PR-A/B and PR-B were normalized according to those of beta-actin to evaluate arbitrary units of the relative abundance of the targets. $\mathrm{C}$ (control), COCs were cultured without any hormone for $20 \mathrm{~h}$. ${ }^{*} P<0.01$, significant effect of $\mathrm{FSH}+\mathrm{LH}$ on the level of $\mathrm{PR}-\mathrm{A} / \mathrm{B}$; ${ }^{* *} P<0.05$, significant effect of $\mathrm{FSH}+\mathrm{LH}$ on the level of PR-B. a,bDifferent superscripts are significantly different at the $P<0.05$ level. Values are means \pm S.E.M. of 3 replicates. (C) Western blotting analysis of PR in cumulus cells. $10 \mathrm{~h}$, COCs were cultured for $10 \mathrm{~h}$ with $\mathrm{FSH}+\mathrm{LH}$. ${ }^{*} P<0.01$, significant effect of additional 10 -h cultivation on the level of $P R-B$; ${ }^{*} P<0.01$, significant effect of additional RU486 following 10-h cultivation with FSH+LH on the level of PR-B. Values are means \pm S.E.M. of 3 replicates. (D) The level of progesterone in the medium where COCs have been cultured for $20 \mathrm{~h}$. Free, COCs were cultured for $20 \mathrm{~h}$ without any hormones. ${ }^{*} P<0.01$, significant effect of $\mathrm{FSH}+\mathrm{LH}$ on the level of progesterone in the cultured medium. ${ }^{a, b}$ Different superscripts are significantly different at the $P<0.05$ level. Values are means \pm S.E.M. of 3 replicates.
} 
A

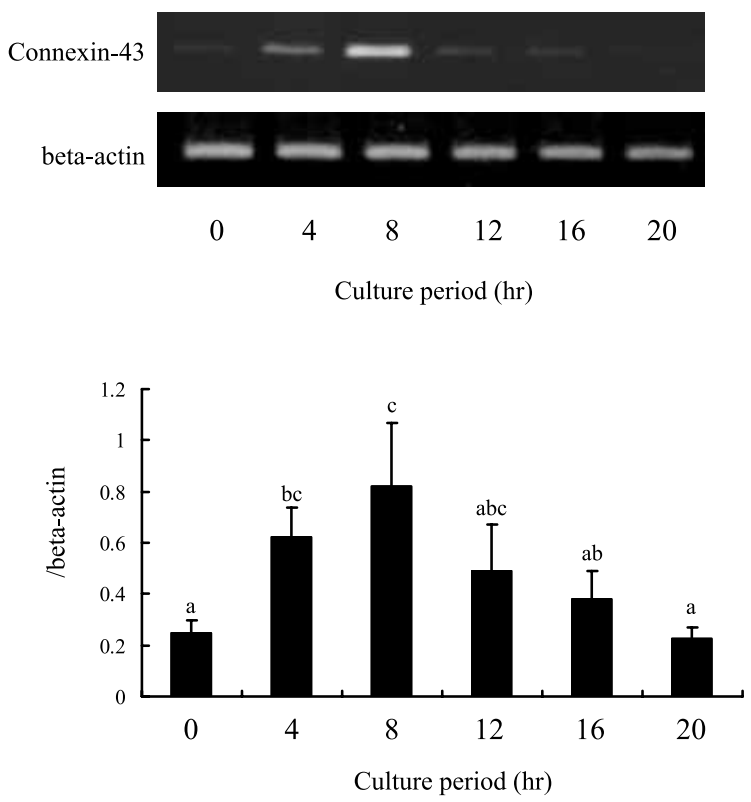

C

Connexin-43

beta-actin
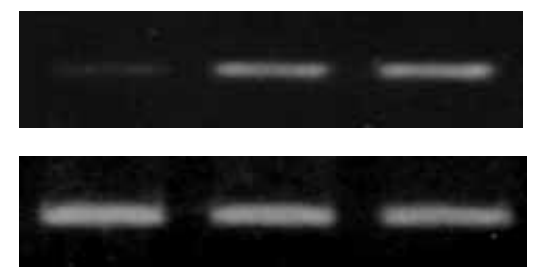

FSH+LH AGT RU486
B
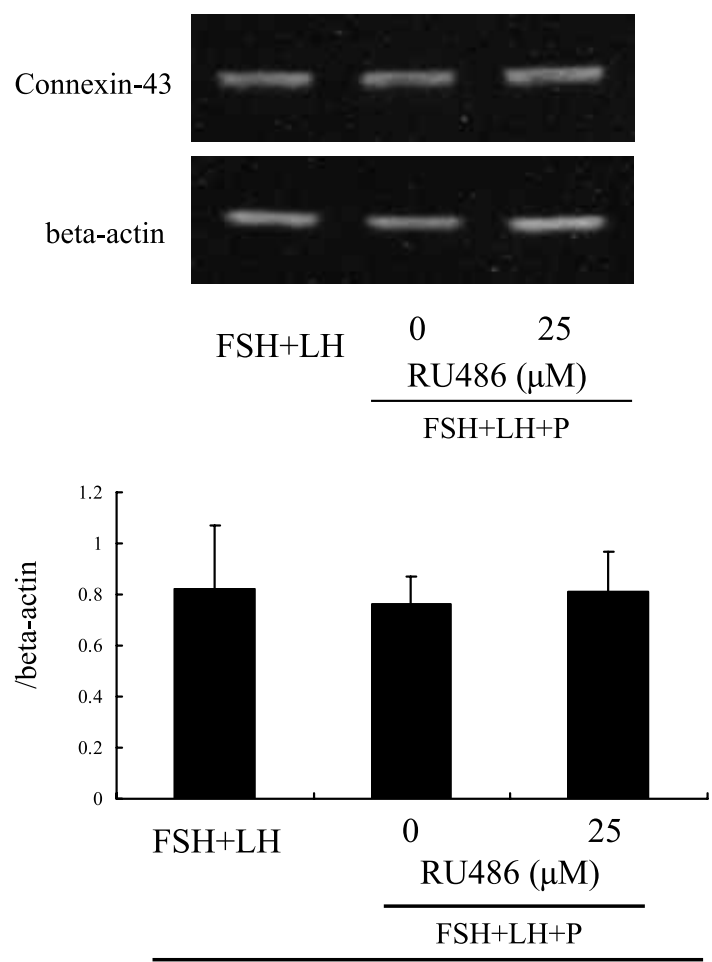

$8 \mathrm{hr}$

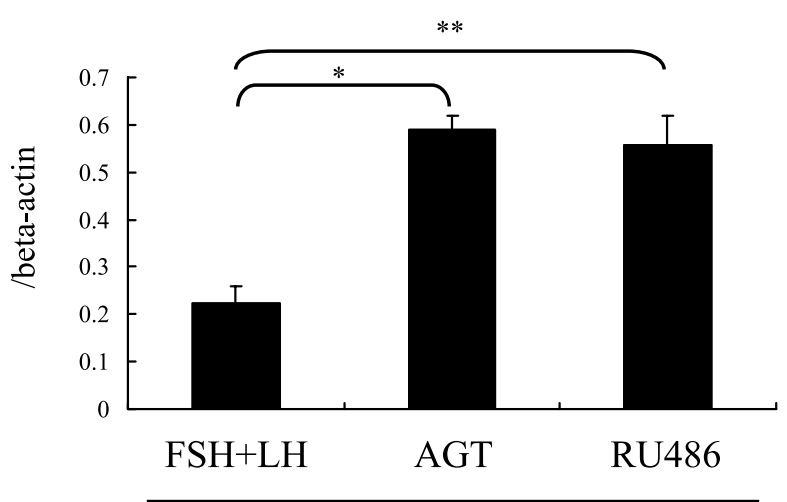

$20 \mathrm{hr}$

Figure 7 Time-dependent changes of connexin-43 gene expression in cumulus cells of COCs and the regulation by progesterone. (A) RT-PCR analysis of connexin-43 mRNA in cumulus cells of COCs which were cultured with $\mathrm{FSH}+\mathrm{LH}$ for up to $20 \mathrm{~h}$. The respective values of connexin-43 were normalized according to those of beta-actin to evaluate arbitrary units of the relative abundance of the targets. ${ }^{a-c}$ Different superscripts are significantly different at the $P<0.05$ level. Values are means \pm S.E.M. of 4 replicates. (B) The level of connexin- 43 mRNA in cumulus cells of COCs cultured with $\mathrm{FSH}+\mathrm{LH}$ for $8 \mathrm{~h}$. $\mathrm{FSH}+\mathrm{LH}+\mathrm{P}$, COCs were cultured for $8 \mathrm{~h}$ in $\mathrm{FSH}+\mathrm{LH}$-containing medium with $20 \mathrm{ng} / \mathrm{ml}$ progesterone and/or $25 \mu \mathrm{M}$ RU486. Values are means \pm S.E.M. of 3 replicates. (C) The effects of AGT or RU486 on the level of connexin-43 mRNA in cumulus cells of COCs cultured for $20 \mathrm{~h}$. AGT, COCs were cultured for $20 \mathrm{~h}$ with $\mathrm{FSH}+\mathrm{LH}$ and $0.5 \mathrm{mM}$ aminoglutethimide. RU486, COCs were cultured for $10 \mathrm{~h}$ with the addition of $25 \mu \mathrm{M}$ RU486 following 10-h cultivation with FSH+LH. ${ }^{*} P<0 \cdot 01$, significant effect of AGT on the level of connexin-43; ${ }^{* \star} P<0.01$, significant effect of additional RU486 following 10-h cultivation on the level of connexin-43. Values are means \pm S.E.M. of 3 replicates. 
may be supposed that the PR-A in cumulus cells is involved not only in the loss of proliferative activity but also in the induction of differentiation. A loss of proliferative activity and differentiation of cumulus cells was also required for meiotic resumption of cumulus-enclosed oocytes (Tanghe et al. 2002). It has been reported that a closing of gap junctional communication in cumulus cell layers is one of the important changes occurring in cumulus cells during meiotic resumption of oocytes (Larsen et al. 1986, 1987, Isobe et al. 1998).

The gap junctional channels are formed by hexametric structures consisting of connexin molecules (connexon) in numerous tissues (GrazulBilska et al. 1997). Porcine ovarian follicles have been reported to express five different connexin genes: connexin-26, connexin-30·3, connexin-32, connexin-43, and connexin-60 (Itahana et al. 1996, 1998). In our previous study (Shimada et al. 2001), a disruption of gap junctional communication in the outer layers of cumulus cells resulted from the disappearance of connexin-43 protein in those layers. Thus, the regulation of connexin-43 gene expression in cumulus cells plays an important role in meiotic resumption of cumulus-enclosed oocytes. The present study showed that the expression of connexin-43 gene was stimulated by cultivation with FSH and LH; however, the depletion of connexin-43 mRNA in cumulus cells of COCs was observed after 12 to $20 \mathrm{~h}$ of cultivation, concomitantly with increasing levels of PR-A expression. The down-regulation of connexin-43 gene expression was prevented by the addition of RU486 or aminoglutethimide. Giangrande et al. (1997) reported that in most cell lines human PR-A functions as a transcriptional repressor, whereas human PR-B functions as a transcriptional activator of progesterone-responsive genes. Moreover, when high levels of PR-B expression were detected in cumulus cells of COCs (8-h cultivation with $\mathrm{FSH}+\mathrm{LH}$ ), the addition of progesterone did not affect the level of connexin-43 mRNA compared with that in cumulus cells cultured with FSH and LH alone. Judging from these results, this is the first report to raise the possibility that a decrease in PR-B levels in cumulus cells is required for down-regulation of connexin-43 gene expression in cumulus cells during meiotic resumption of oocytes.

It has been reported that the in vivo administration of anti-progestin antiserum into
PMSG+hCG-treated female rats significantly decreases the incidence of meiotic resumption of oocytes within the large follicles (Mori et al. 1983). Osborn et al. (1986) also reported that when ovine follicles were cultured with FSH, LH and the P450 scc inhibitor AGT, the result was an almost complete inhibition of progesterone production and meiotic progression to the metaphase II stage in oocytes. Unexpectedly, the addition of progesterone receptor antagonist did not suppress meiotic resumption of mouse oocytes (Batten et al. 1989) and porcine oocytes (in the present study). The present study also showed that the predominant isoforms of PR expressed in cumulus cells shifted from PR-B to PR-A during the time course of COCs' cultivation with FSH and LH. Treatment with RU486 following a 10-h cultivation inhibited the meiotic resumption of porcine cumulusenclosed oocytes, suggesting that the decrease in PR-B levels in cumulus cells was involved in meiotic resumption of porcine oocytes.

Analysis of histology of PR null mice has revealed normal development of intraovarian follicles to the tertiary follicular stage, and the follicles contain a mature oocyte that is fully functional when isolated and fertilized in vitro (Lydon et al. 1995). Despite the failure of ovulation to occur in PR null mice, cumulus cell expansion proceeds normally (Robker et al. 2000). The cultivation of porcine COCs with RU486 from 0 to $44 \mathrm{~h}$ had less of an effect on the induction of meiotic resumption and slightly affected the progression to the MII stage; however, the matured oocytes had little developmental competence to proceed to the blastocyst stage. Additionally, cumulus cells became flattened on the culture dish with few remaining suspended in the expanded complex. The present results indicate that the PR-dependent pathway in cumulus cells is essential for normal in vitro maturation of porcine oocytes, but in mouse the oocytes may not be dependent on this pathway. The differences of PR expression among the species were also observed during follicular development in ovaries. In rodent and primate ovaries, follicles that developed beyond the primary stage no longer expressed PR in granulosa cells until after the surge of LH, and the LH surge induced a rapid increase in expression of PR in granulosa cells (Hild-Petito et al. 1988, Park \& Mayo 1991, Shao et al. 2003). In pig, early antral follicles contained PR in granulosa cells, and the 
A

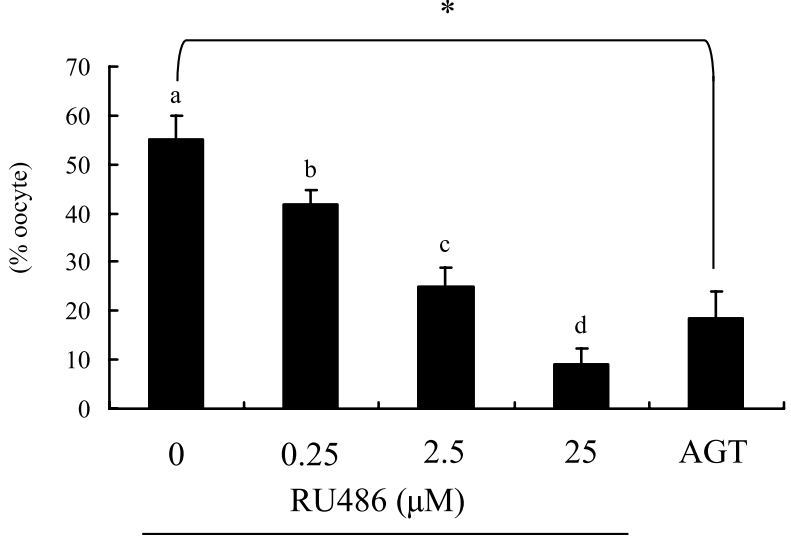

$\mathrm{FSH}+\mathrm{LH}$

B

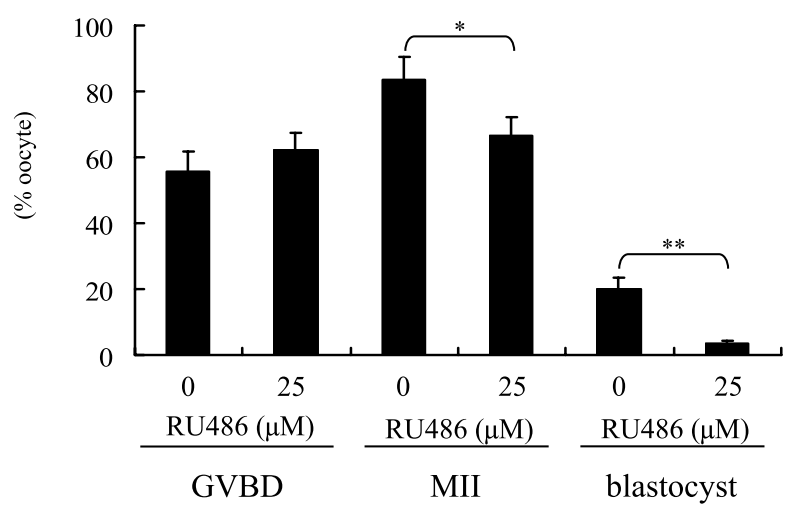

$\mathrm{C}$

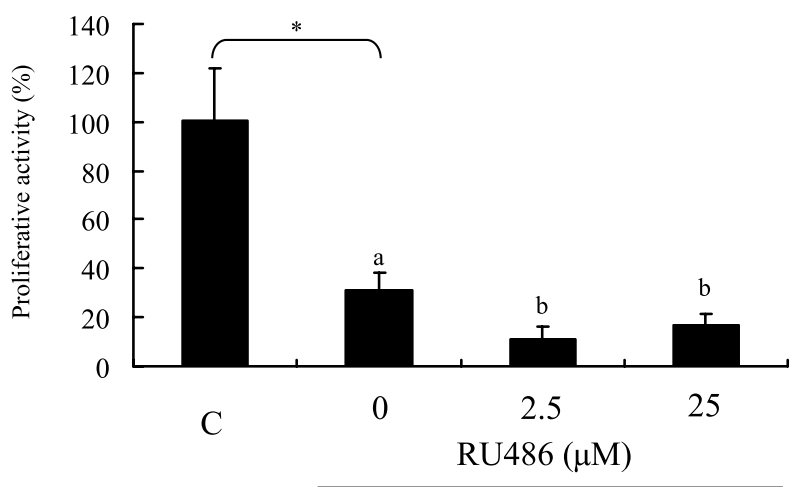

$\mathrm{FSH}+\mathrm{LH}$
$\mathrm{D}$

(a)

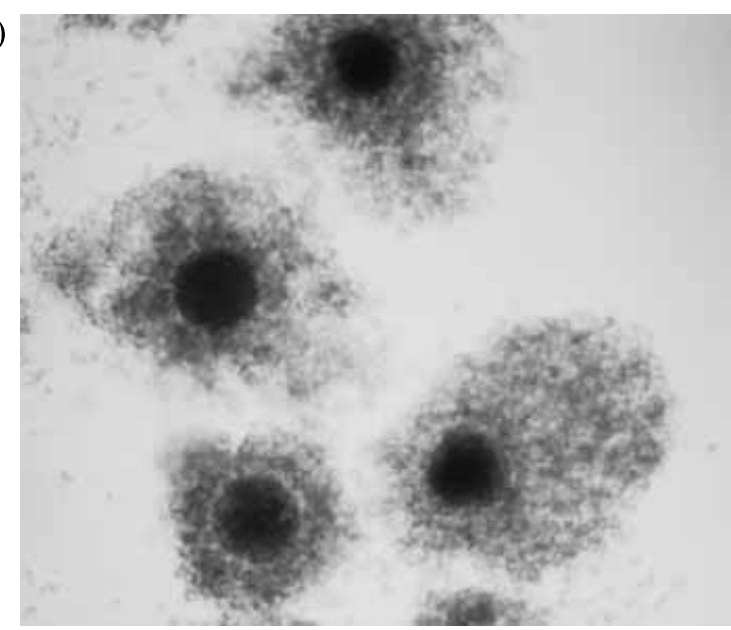

(b)

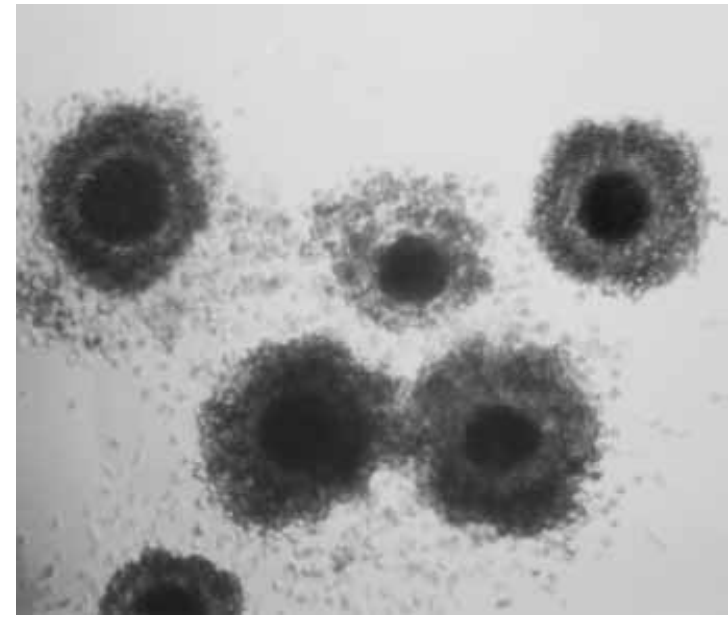

(c)

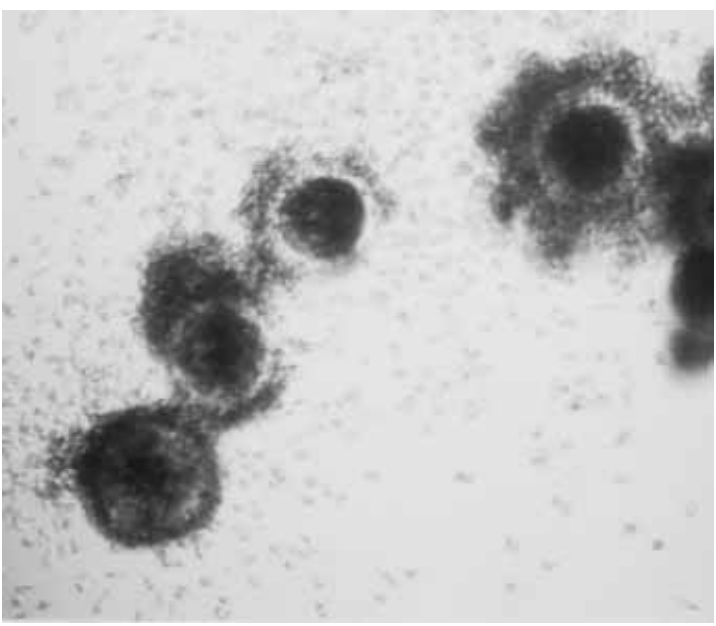


stimulation of FSH increased the level in granulosa cells (Slomczynska et al. 2000). In dog, Vermeirsch et al. (2001) reported that the amount of PR in granulosa cells increased with the stage of follicle development, the level being significantly higher in the secondary and tertiary follicles compared with the primordial and primary follicles. Yoshimura et al. (1995) showed in chicken ovary that both PR-A and PR-B were expressed in small antral follicles but only PR-A was expressed in large antral follicles. These reports, including our own study, indicate that the role of PR in follicle cells should be investigated more thoroughly in each species to understand the mechanisms of follicular development and in vitro maturation of oocytes.

In summary, PR-B was predominantly expressed in cumulus cells of COGs cultured with FSH and LH. However, the level of PR-B mRNA dropped significantly at $12 \mathrm{~h}$, whereas a high level of total PR mRNA was maintained up to $20 \mathrm{~h}$. Accompanying the decrease of PR-B levels in cumulus cells, the loss of proliferative activity, down-regulation of connexin-43 gene expression and progesterone production in cumulus cells were also observed. The addition of RU486 after 10-h cultivation of COCs with FSH and LH suppressed the functional changes of cumulus cells and the meiotic resumption of oocytes. These results suggest that the induction of PR isoforms in cumulus cells and their binding to progesterone appear to have an impact on proliferation and differentiation in a time-dependent manner, and the shift from PR-B to PR-A may help mediate certain events. The differentiation of cumulus cells mediated by a
PR-dependent pathway is essential for meiotic resumption of porcine oocytes in vitro.

\section{Acknowledgements}

This work was partly supported by Grant-in-Aid for Scientific Research (to M S; No.14760179) and a Research Fellowship for Young Scientist (to J I; No.08254) from the Japan Society for the Promotion of Science. Porcine FSH and LH were kindly provided by Dr A F Parlow, the National Hormone and Pituitary Program, the National Institute of Diabetes and Digestive and Kidney Disease, USA. Thanks are due to Dr Takahide Mori, Professor Emeritus of Kyoto University, for stimulating discussion and valuable comments, and to Dr Masanori Fujita, Professor of Hiroshima University, for technical advice on the use of HPLC-UV analysis. We thank the staff of the Meat Inspection Office in Hiroshima City for supplying the porcine ovaries.

\section{References}

Altschul SF, Gish W, Miller W, Myers EW \& Lipman DJ 1990 Basic local alignment search tool. Fournal of Molecular Biology 215 403-410.

Armstrong DT, Xia P, de-Gannes G, Tekpetey FR \& Khamsi F 1996 Differential effects of insulin-like growth factor-I and follicle-stimulating hormone on proliferation and differentiation of bovine cumulus cells and granulosa cells. Biology of Reproduction 54 331-338.

Batten BE, Roh SI \& Kim MH 1989 Effects of progesterone and a progesterone antagonist (RU486) on germinal vesicle breakdown in the mouse. Anatomical Record 223 387-392.

Figure 8 The effects of RU486 on the oocyte maturation in vitro. (A) The proportion of oocytes exhibiting GVBD when COCs were cultured for $10 \mathrm{~h}$ with additional RU486 (0 to $25 \mu \mathrm{M}$ ) after 10-h cultivation with $\mathrm{FSH}+\mathrm{LH}$. RU486, COCs were cultured for $10 \mathrm{~h}$ with $\mathrm{FSH}+\mathrm{LH}$, and further cultured for 10-h with $0,0.25,2.5$ or $25 \mu \mathrm{M}$ RU486. AGT, COCs were cultured for $20 \mathrm{~h}$ with $\mathrm{FSH}+\mathrm{LH}$ and $0.5 \mathrm{mM}$ aminoglutethimide. ${ }^{*}$ The additional effect of $0.5 \mathrm{mM}$ AGT to $\mathrm{FSH}+\mathrm{LH}$-containing medium is significant $(P<0.01)$. ${ }^{\mathrm{a}-\mathrm{d}}$ Different superscripts are significantly different at the $P<0.05$ level. Values are means \pm S.E.M. of 4 replicates. (B) COCs were cultured for 20 or $44 \mathrm{~h}$ with $\mathrm{FSH}+\mathrm{LH}$ and/or $25 \mu \mathrm{M}$ RU486. The proportion of oocytes exhibiting GVBD or that reached metaphase II (MII) stage was checked after $20 \mathrm{~h}$ or $44 \mathrm{~h}$ of cultivation respectively. The developmental competence of matured oocytes to progress to the blastocyst stage was checked at 5 days after in vitro fertilization. ${ }^{*} P<0.05$, significant effect of RU486 on the number of oocytes that reached the MII stage; ${ }^{* \star} P<0.01$, significant effect of RU486 on the developmental competence to progress to the blastocyst stage after in vitro fertilization. Values are means \pm S.E.M. of 3 replicates. (C) Proliferative activity of cumulus cells of COCs cultured for $44 \mathrm{~h}$ with $\mathrm{FSH}+\mathrm{LH}$ and RU486 (0 to $25 \mu \mathrm{M}$ ). Data are expressed as percentage of the absorbance value at $450 \mathrm{~nm}$ in cumulus cells of COCs which were cultured for $44 \mathrm{~h}$ in the Free medium with $100 \mu \mathrm{M}$ BrdU. C (control), COCs were cultured for $44 \mathrm{~h}$ with $100 \mu \mathrm{M} \mathrm{BrdU.}{ }^{*} P<0.01$, significant effect of $\mathrm{FSH}+\mathrm{LH}$ on proliferative activity of cumulus cells. ${ }^{\mathrm{a}-\mathrm{c}}$ Different superscripts are significantly different at the $P<0.05$ level. Values are means \pm S.E.M. of 3 replicates. (D) The expanded COCs were observed after 44-h cultivation with $\mathrm{FSH}+\mathrm{LH}$. (a) COCs were cultured for $44 \mathrm{~h}$ with $\mathrm{FSH}+\mathrm{LH}$. (b) COCs were cultured for $34 \mathrm{~h}$ with additional $25 \mu \mathrm{M}$ RU486 after 10-h cultivation with FSH+LH. (c) COCs were cultured for $44 \mathrm{~h}$ with FSH+LH and $25 \mu \mathrm{M}$ RU486. 
Beato M, Chalepakis G, Schauer M \& Slater EP 1989 DNA regulatory elements for steroid hormones. Fournal of Steroid Biochemistry 32 737-747.

Chian RC, Ao A, Clarke HJ, Tulandi T \& Tan S 1999 Production of steroids from human cumulus cells treated with different concentrations of gonadotropins during culture in vitro. Fertility and Sterility 71 61-66.

Clemens JW, Robker RL, Kraus WL, Katzenellenbogen BS \& Richards JS 1998 Hormone induction of progesterone receptor (PR) messenger ribonucleic acid and activation of $\mathrm{PR}$ promoter regions in ovarian granulosa cells: evidence for a role of cyclic adenosine 3',5'-monophosphate but not estradiol. Molecular Endocrinology 12 1201-1214.

Conneely OM, Mulac-Jericevic B, Lydon JP \& De Mayo FJ 2001 Reproductive functions of the progesterone receptor isoforms: lessons from knock-out mice. Molecular Cellular Endocrinology 179 97-103.

Coskun S, Uzumcu M, Lin YC, Friedman CI \& Alak BM 1995 Regulation of cumulus cell steroidogenesis by the porcine oocyte and preliminary characterization of oocyte-produced factor(s). Biology of Reproduction 53 670-675.

De-Vivo I, Huggins GS, Hankinson SE, Lescault PJ, Boezen M, Colditz GA \& Hunter DJ 2002 A functional polymorphism in the promoter of the progesterone receptor gene associated with endometrial cancer risk. PNAS 99 12263-12268.

Fang X, Wong S \& Mitchell BF 2002 Messenger RNA for progesterone receptor isoforms in the late-gestation rat uterus. American Fournal of Physiology. Endocrinology Metabolism 283 E1167-E1172.

Fazzari A, Catalano MG, Comba A, Becchis M, Raineri M, Frairia R \& Fortunati N 2001 The control of progesterone receptor expression in MCF-7 breast cancer cells: effects of estradiol and sex hormone-binding globulin (SHBG). Molecular Cellular Endocrinology 172 31-36.

Giangrande PH, Pollio G \& McDonnell DP 1997 Mapping and characterization of the functional domains responsible for the differential activity of the $\mathrm{A}$ and $\mathrm{B}$ isoforms of the human progesterone receptor. Fournal of Biological Chemistry 272 32889-32900.

Grazul-Bilska AT, Reynolds LP \& Redmer DA 1997 Gap junctions in the ovaries. Biology of Reproduction 57 947-957.

Hild-Petito S, Stouffer RL \& Brenner RM 1988 Immunocytochemical localization of estradiol and progesterone receptors in the monkey ovary throughout the menstrual cycle. Endocrinology 123 2896-2905.

Isobe N, Maeda T \& Terada T 1998 Involvement of meiotic resumption in the disruption of gap junctions between cumulus cells attached to pig oocytes. Fournal of Reproduction and Fertility 113 167-172.

Itahana K, Morikazu Y \& Takeya T 1996 Differential expression of four connexin genes, $\mathrm{Cx}_{\mathrm{x}}-26, \mathrm{Cx}-30 \cdot 3, \mathrm{Cx}_{\mathrm{x}}-32$ and $\mathrm{Cx}-43$, in the porcine ovarian follicle. Endocrinology 137 5036-5044.

Itahana K, Tanaka T, Morikazu Y, Komatu S, Ishida N \& Takeya $\mathrm{T} 1998$ Isolation and characterization of a novel connexin gene, $\mathrm{Cx}-60$, in the porcine ovarian follicles. Endocrinology 139 320-329.

Iwai T, Fujii S, Nanbu Y, Nonogaki H, Konishi I, Mori T \& Okamura H 1991 Effect of human chorionic gonadotropin on the expression of progesterone receptors and estrogen receptors in rabbit ovarian granulosa cells and the uterus. Endocrinology 129 1840-1848.

Jo M, Komar CM \& Fortune JE 2002 Gonadotropin surge induces two separate increases in messenger RNA for progesterone receptor in bovine preovulatory follicles. Biology of Reproduction $\mathbf{6 7}$ 1981-1988.

Kraus WL, Montano MM \& Katzenellenbogen BS 1993 Cloning of the rat progesterone receptor gene 5'-region and identification of two functionally distinct promoters. Molecular Endocrinology 7 $1603-1616$.

Kraus WL, Montano MM \& Katzenellenbogen BS 1994 Identification of multiple, widely spaced estrogen-responsive regions in the rat progesterone receptor gene. Molecular Endocrinology 8 952-969.

Larsen WJ, Wert SE \& Brunner GD 1986 A dramatic loss of cumulus cell gap junctions is correlated with germinal vesicle breakdown in rat oocytes. Developmental Biology 113 517-521.

Larsen WJ, Wert SE \& Brunner GD 1987 Differential modulation of rat follicle cell gap junction populations at ovulation. Developmental Biology 122 61-71.

Lydon JP, DeMayo FJ, Funk CR, Mani SK, Hughes AR, Montgomery CA Jr, Shyamala G, Conneely OM \& O'Malley BW 1995 Mice lacking progesterone receptor exhibit pleiotropic reproductive abnormalities. Genes and Development 9 2266-2278.

Mori T, Morimoto N, Kohda H, Nishimura T \& Kambegawa A 1983 Meiosis-inhibiting effects in vivo of antiserum to progesterone on follicular ova in immature rats treated with gonadotropins. Endocrinologia Faponica 30 593-599.

Mulac-Jericevic B, Mullinax RA, DeMayo FJ, Lydon JP \& Conneely OM 2000 Subgroup of reproductive functions of progesterone mediated by progesterone receptor-B isoform. Science $\mathbf{2 8 9}$ $1751-1754$

Mulac-Jericevic B, Lydon JP, DeMayo FJ \& Conneely OM 2003 Defective mammary gland morphogenesis in mice lacking the progesterone receptor B isoform. PNAS 100 9744-9749.

Mussche S \& D'Herde K 2001 Contribution of progesterone, follicle stimulating hormone and glucocorticoids in survival of serum-free cultured granulosa cell explants. Fournal of Endocrinology 169 321-331.

Natraj U \& Richards JS 1993 Hormonal regulation, localization, and functional activity of the progesterone receptor in granulosa cells of rat preovulatory follicles. Endocrinology 133 761-769.

Osborn JC, Moor RM \& Crosby IM 1986 Effect of alterations in follicular steroidogenesis on the nuclear and cytoplasmic maturation of ovine oocytes. Foumal of Embryology and Experimental Morphology 98 187-208.

Park OK \& Mayo KE 1991 Transient expression of progesterone receptor messenger RNA in ovarian granulosa cells after the preovulatory luteinizing hormone surge. Molecular Endocrinology 5 967-978.

Park JI, Kim WJ, Wang L, Park HJ, Lee J, Park JH, Kwon HB, Tsafriri A \& Chun SY 2000 Involvement of progesterone in gonadotrophin-induced pituitary adenylate cyclase-activating polypeptide gene expression in pre-ovulatory follicles of rat ovary. Molecular Human Reproduction 6 238-245.

Petters RM \& Reed ML 1991 Addition of taurine or hypotaurine to culture medium improves development of one- and two-cell pig embryos in vitro. Theriogenology 35253 (Abstract).

Racowsky C 1985 Effect of forskolin on maintenance of meiotic arrest and stimulation of cumulus expansion, progesterone and cyclic AMP production by pig oocyte-cumulus complexes. Fournal of Reproduction and Fertility 74 9-21.

Robker RL, Russell DL, Espey LL, Lydon JP, O’Malley BW \& Richards JS 2000 Progesterone-regulated genes in the ovulation process: ADAMTS-1 and cathepsin L proteases. PNAS 97 4689-4694.

Schuetz AW, Whittingham DG \& Snowden R 1996 Alterations in the cell cycle of mouse cumulus granulosa cells during expansion and mucification in vivo and in vitro. Reproductive Fertility and Development 8 935-943.

Shao R, Markstrom E, Friberg PA, Johansson M \& Billig H 2003 Expression of progesterone receptor (PR) A and B isoforms in mouse granulosa cells: stage-dependent PR-mediated regulation of apoptosis and cell proliferation. Biology of Reproduction $\mathbf{6 8}$ 914-921. 
Shimada M \& Terada T 2001 Phosphatidylinositol 3-kinase in cumulus cells and oocytes is responsible for activation of oocyte mitogen activated protein kinase during meiotic progression beyond the MI stage in pigs. Biology of Reproduction 64 1106-1114.

Shimada M \& Terada T 2002a FSH and LH induce progesterone production and progesterone receptor synthesis in cumulus cells; a requirement for meiotic resumption in porcine oocytes. Molecular Human Reproduction 8 612-618.

Shimada M \& Terada T 2002b Roles of cAMP in regulation of both MAP kinase and p34 $4^{\text {cdc2 }}$ kinase activity during meiotic progression, especially beyond the MI stage. Molecular Reproduction and Development 62 124-131.

Shimada M, Maeda T \& Terada T 2001 Dynamic changes of connexin-43, gap junctional protein, in outer layers of cumulus cells are regulated by PKC and PI 3-kinase during meiotic resumption in porcine oocytes. Biology of Reproduction $\mathbf{6 4}$ $1255-1263$.

Shimada M, Samizo N, Yamashita Y, Matsuo K \& Terada T 2002 Both $\mathrm{Ca}^{2+}$-PKC pathway and cAMP-PKA pathway required for progesterone production in FSH- and LH-stimulated cumulus cells during in vitro maturation of porcine oocytes. Fournal of Mammalian Ova Research 19 81-88.

Shimada M, Nishibori M, Isobe N, Kawano N \& Terada T 2003 Luteinizing hormone receptor formation in cumulus cells surrounding porcine oocytes and its role during meiotic maturation of porcine oocytes. Biology of Reproduction $\mathbf{6 8}$ $1142-1149$.

Shiozawa T, Horiuchi A, Kato K, Obinata M, Konishi I, Fujii S \& Nikaido T 2001 Up-regulation of p27 Kipl by progestins is involved in the growth suppression of the normal and malignant human endometrial glandular cells. Endocrinology 142 4182-4188.

Slomczynska M, Krok M \& Pierscinski A 2000 Localization of the progesterone receptor in the porcine ovary. Acta Histochemica 102 183-191.

Tanghe S, Van Soom A, Nauwynck H, Coryn M \& de Kruif A 2002 Functions of the cumulus oophorus during oocyte maturation, ovulation, and fertilization. Molecular Reproduction and Development 6414424.

Turgeon JL \& Waring DW 2000 Progesterone regulation of the progesterone receptor in rat gonadotropes. Endocrinology 141 3422-3429.

VandeVoort CA, Overstreet JW, Lasley BL \& Stewart DR 2000 Effects of progesterone receptor blockers on human granulosa-luteal cell culture secretion of progesterone, estradiol, and relaxin. Biology of Reproduction 62 200-205.

Vermeirsch H, Simoens P, Coryn M \& Van den Broeck W 2001 Immunolocalization of progesterone receptors in the canine ovary and their relation to sex steroid hormone concentrations. Reproduction 122 73-83.

Xia P, Tekpetey FR \& Armstrong DT 1994 Effects of IGF-I on pig oocyte maturation, fertilization, and early embryonic development in vitro, and on granulosa and cumulus cell biosynthetic activity. Molecular Reproduction and Development 38 373-379.

Yamashita Y, Shimada M, Okazaki T, Maeda T \& Terada T 2003 Production of progesterone from de novo-synthesized cholesterol in cumulus cells and its physiological role during meiotic resumption of porcine oocytes. Biology of Reproduction 68 1193-1198.

Yoshimura Y, Okamoto T \& Tamura T 1995 Effects of luteinizing hormone and follicle-stimulating hormone on the progesterone receptor induction in chicken granulosa cells in vivo. Poultry Science 74 147-151.

Zhang X \& Armstrong DT 1989 Effects of follicle-stimulating hormone and ovarian steroids during in vitro meiotic maturation on fertilization of rat oocytes. Gamete Research 23 267-277.

Zhao K, Kuperman L, Geimonen E \& Andersen J 1996 Progestin represses human connexin-43 gene expression similarly in primary cultures of myometrial and uterine leiomyoma cells. Biology of Reproduction 54 607-615.

\section{Received 13 October 2003 Accepted 10 May 2004}

